\title{
PENGARUH KUALITAS PRODUK DAN HARGA TERHADAP KEPUTUSAN PEMBELIAN PRODUK WIPOL PADA SAAT PANDEMI WABAH COVID-19 STUDI KASUS DI KECAMATAN MEDAN POLONIA
}

\author{
Juli Mandasari, Nur'ain Harahap, Syahraini \\ Fakultas Ekonomi, Universitas Muslim Nusantara Al Washliyah, Program Studi Manajemen \\ Email: juli.mandasari09@gmail.com
}

\begin{abstract}
The pandemic outbreak has an impact on the decline in the economic capacity of the community. one of which has an impact on the sales of WIPOL products. Therefore, researchers are motivated to understand whether product quality and price affect the purchasing decisions of WIPOL products in Medan Polonia District. The study has a quantitative descriptive analysis type, 99 samples were calculated based on the Slovin formula. The results obtained are product quality and price affect purchasing decisions either separately or together. The value of the coefficient of determination (R2) was obtained at $70.8 \%$. It can be interpreted that product quality and price contribute to the influence of people's purchasing decisions by $70.8 \%$ and the rest are influenced by other elements.
\end{abstract}

Keywords: product quality, price, purchase decision

\begin{abstract}
Abstrak
Wabah pandemi memberi dampak pada menurunnya kemampuan ekonomi masyarakat. salah satunya berdampak pada penjualan produk WIPOL. Oleh karena itu, Peneliti termotivasi untuk memahami apakah kualitas produk dan harga berpengaruh terhadap keputusan pembelian produk WIPOL di Kecamatan Medan Polonia. studi memiliki jenis analisa deskriptif kuantitatif, 99 sampel dihitung berpatokan pada rumus slovin. Hasil yang diperoleh yaitu kualitas produk dan harga terhadap keputusan pembelian berpengaruh baik secara terpisah maupun secara bersama. Nilai koefisien determinasi $\left(\mathrm{R}^{2}\right)$ didapatkan sebesar 70,8\%. Dapat dimaknai bahwa kualitas produk dan harga berkontribusi terhadap pengaruh keputusan pembelian masyarakat sebesar $70,8 \%$ dan selebihnya dipengaruhi unsur lainnya.
\end{abstract}

Kata kunci : kualitas produk, harga, keputusan pembelian

\section{Pendahuluan}

Aspek-aspek yang telah terdampak pandemi merata, menghancurkan perekonomian baik nasional maupun internasional. Hal ini merupakan sebuah bencana besar yang melanda penduduk bumi. Yang paling berimbas adalah bidang perekenomian, dengan menanggung perubahan yang sangat signifikan ke arah keterpurukan sejak adanya pandemic
COVID ini. Indonesia merupakan satu diantara banyak negara yang terinfeksi pandemi COVID-19 yang mencatat perkembangan penderita yang semakin pesat terdata 1.166 .079 orang positif virus corona, diantaranya, 963.028 orang berhasil sembuh, dan 31.763 orang meninggal dunia (Prastiwi:2021).

Di dalam dunia usaha, kualitas barang mempunyai hubungan yang erat 
sekali dengan harga. Anggapan mengenai kualitas produk oleh konsumen terhadap Produk disinfektan Wipol berasal dari informasi yang diperoleh konsumen mengenai produk tersebut. Namun konsumen beranggapan bahwa semua produk disinfektan memiliki fungsi yang sama, sehingga penilaian terhadap kualitas produk tiap produk juga sama. Pada produk disinfektan wipol, pembeli berasumsi bahwa harga yang diberlakukan itu mahal, oleh karena itu Pembeli akan memikirkan ulang untuk melakukan keputusan pembelian. Maka dari kejadian tersebut, menjadikan perusahaan Unilever selaku pemilik produk disinfektan mengambil tindakan untuk tetap menjaga kualitas produk dan harga yang ia miliki.

Kotler \& Amstrong (2015) memberikan pengertian tentang harga yang merupakan sejumlah nilai uang yang dibarterkan dengan nilai produk. Lebih lanjut, harga dapat digambarkan sebagai nilai tertentu yang barterkan oleh pembeli untuk memperoleh manfaat atas penggunaan suatu barang ataupun jasa. Untuk itu harga merupakan suatu hal yang perlu dicermati oleh konsumen di saat proses pembelian, seyogianya konsumen akan melaksanakan identifikasi harga terhadap nilai. Apabila semakin tinggi pembeli merasakan kegunaan produk, maka semakin tinggi pula nilai tukar barang tersebut. meningkatnya angka penjualan produk WIPOL pada keadaan ini merupakan dampak yang ditimbulkan oleh adanya pandemi, karena adanya asumsi bahwa disinfektan dapat membunuh kuman.

Menghadapi Kondisi nyata saat ini, maka pihak pengusaha harus mampu memberikan kepuasan serta pelayanan maksimal kepada konsumen yang merupakan tujuan inti dari perusahaan dimana memberlakukan konsep pemasaran.

Konsumen yang merasa puas inilah yang nantinya akan diprediksi untuk melakukan pembelian produk kembali. Sehingga tujuan perusahaan memperoleh keuntungan dapat dipergunakan untuk melakukan pembiayaan operasional supaya semakain tumbuh dan berkembang.

Dilihat dari faktor harga dan kualitas, produk Wipol memiliki harga yang bersaing dengan produk disinfektan yang lainnya. Berikut daftar harga produk disinfektan di Kecamatan Medan Polonia:

Tabel 1. Estimasi Harga Produk Disinfektan Di Kecamatan Medan Polonia 2020

\begin{tabular}{|c|c|r|l|}
\hline No & Produk & Berat Bersih & Harga Eceran \\
\hline 1 & Wipol & $780 \mathrm{ml}$ & 19.000 \\
\hline 3 & Supersol & $770 \mathrm{ml}$ & 16.700 \\
\hline 4 & SOS & $750 \mathrm{ml}$ & 11.300 \\
\hline
\end{tabular}

Sumber: Disperindag, Tahun 2020 
Mengacu kepada hasil tabel di atas diketahui bahwa produk WIPOL masih mahal dari harga produk disinfektan yang pesaing, yakni sebesar 19.000 untuk harga eceran yang mengakibatkan suatu keputusan suatu pembelian oleh masyarakat akan mempertimbangkan kembali untuk mealakukan keputusan pembelian atas produk wipol.

\section{Tabel 2. Penjualan Produk Wipol} Kecamatan Medan Polonia Per Bulan Tahun 2020

\begin{tabular}{|c|l|l|l|l|}
\hline No & Bulan & $\begin{array}{l}\text { Qty/Unit } \\
\text { Terjual }\end{array}$ & Penjualan & $\begin{array}{l}\text { Target } \\
\text { Penjualan }\end{array}$ \\
\hline 1 & Januari & 635 pcs & Rp 8.472 .805 & Rp 8.500 .000 \\
\hline 2 & Februari & 642 pcs & Rp 8.566 .206 & Rp 8.500 .000 \\
\hline 3 & Maret & 650 pcs & Rp 8.672 .950 & Rp 8.500 .000 \\
\hline 4 & April & 896 pcs & Rp11.955.627 & Rp11.900.000 \\
\hline 5 & Mei & 998 pcs & Rp13.316.647 & Rp11.900.000 \\
\hline 6 & Juni & 1109 pcs & Rp14.797.757 & Rp11.900.000 \\
\hline 7 & Juli & 1154 pcs & Rp15.398.207 & Rp13.090.000 \\
\hline 8 & Agustus & 1074 pcs & Rp14.330.740 & Rp13.090.000 \\
\hline 9 & September & 1023 pcs & Rp13.650.230 & Rp13.090.000 \\
\hline 10 & Oktober & 942 pcs & Rp12.569.420 & Rp13.774.500 \\
\hline 11 & November & 899 pcs & Rp11.995.657 & Rp13.774.500 \\
\hline 12 & Desember & 878 pcs & Rp11.715.447 & Rp13.774.500 \\
\hline
\end{tabular}

Sumber: Depo Unilever Medan,2020

Berdasarkan tabel 2 diatas diketahui bahwa terjadinya penurunan jumlah unit penjualan produk Wipol Kecamatan Medan Polonia akhir tahun 2020, yakni pada bulan Oktober, November, Desember sehingga tidak tercapainya target penjualan yang diinginkan diakibatkan karena keputusan suatu pembelian oleh masyarakat akan beralih dari penggunaan produk disinfektan WIPOL ke handsanitizer yang lebih praktis untuk dibawa kemana-mana yang bisa disebabkan karena kualitas produk wipol masih belum maksimal dan harga wipol masih relatif mahal di Kecamatan Medan Polonia.

Merangkum keseluruhan penjabaran di atas, penulis bertujuan untuk melaksanakan penelitian demi untuk mengetahui kualitas produk dan harga apakah mempunyai pengaruh terhadap keputusan pembelian.

\section{Tinjauan Pustaka}

Sangadji (2013:123) berpendapat keputusan melaksanakan pembelian merupakan proses memecahkan masalah yang digiring pada tujuan. Dengan kata lain keputusan pembelian merupakan tindakan konsumen yang memiliki komitmen dalam pengambilan keputusan pembelian.

Menurut Nasution (2015:2) kualitas produk yaitu "kesesuaian pemakaian produk (fitness for use) untuk mencukupi keperluan dan kepuasan Pembeli. Tandjung (2014:78) berpendapat tentang harga yang merupakan sejumlah dana yang telah disetujui oleh yang akan menjadi konsumen dan yang mendagangkan barangnya untuk dibarterkan dengan barang atau jasa dalam jual beli bisnis sebenarnya. kerangka konseptual penelitian dapat ditampilkan 
sebagaimana yang tertera di bawah ini:

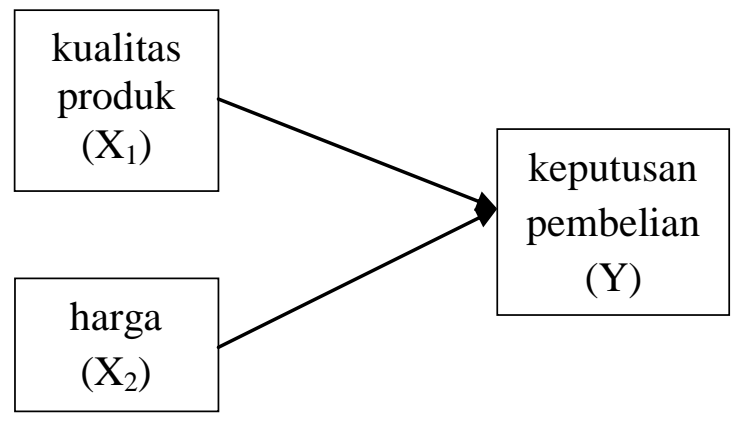

Sumber: peneliti 2021

\section{Gambar 1. kerangka konseptual}

Berlandaskan kerangka konseptual tersebut, dapat diformulasikan bahwa jawaban sementara (hipotesa) dalam penelitian ini yaitu:

$\mathrm{H}_{1}=$ Ada pengaruh variabel kualitas produk yang positif dan signifikan terhadap keputusan pembelian produk WIPOL ditengah pandemi wabah Covid 19 studi kasus Kecamatan Medan Polonia.

$\mathrm{H}_{2}=$ Ada pengaruh diantara variabel harga terhadap keputusan pembelian yang positif serta signifikan pada produk WIPOL ditengah pandemi wabah Covid 19 studi kasus Kecamatan Medan Polonia.

$\mathrm{H}_{3}=$ Ada pengaruh variabel kualitas produk dan harga secara serentak yang positif serta signifikan terhadap keputusan pembelian pada produk
WIPOL ditengah pandemi wabah Covid19 studi kasus Kecamatan Medan Polonia.

\section{Metode Penelitian}

Yang dipergunakan pada analisa ini mengacu kepada metode deskriptif kuantitatif. Kajian ini di dilaksanakan di Kecamatan Medan Polonia. mengumpulkan bahan kajian dengan teknik observasi, dan kuesioner. Populasi pada kajian ini merupakan masyarakat Kecamatan Medan Polonia. Penarikan sampel memanfaatkan metode random sampling (mengambil sampel secara tidak beraturan). Penarikan sampel dalam memanfaatkan rumus slovin dengan hasil yang diperoleh sebanyak 99 responden. Untuk mengetahui pengaruh kualitas produk dan harga berpengaruh terhadap keputusan pembelian digunakan rumus analisis regresi linier berganda dengan persamaan: $\mathrm{Y}=\mathrm{a}+\mathrm{b}_{1} \mathrm{X}_{1}+\mathrm{b}_{2} \mathrm{X}_{2}+\mathrm{e}$

\section{Hasil penelitian dan Pembahasan}

\subsection{Hasil Penelitian}

\section{Uji Validitas dan reliabilitas}

Sebelum data digunakan untuk menentukan hasil, dilakukan uji validitas dan reliabilitas untuk data yang telah terkumpul. Hasil output dari olahan data tersebut adalah: 
Tabel 3. Validitas kualitas produk (x1)

\begin{tabular}{|l|r|r|r|r|r|}
\hline \multicolumn{7}{|c|}{ Item-Total Statistics } \\
\hline & $\begin{array}{c}\text { Scale Mean if } \\
\text { Item Deleted }\end{array}$ & $\begin{array}{c}\text { Scale } \\
\text { Variance if } \\
\text { Item Deleted }\end{array}$ & $\begin{array}{c}\text { Corrected } \\
\text { Item-Total } \\
\text { Correlation }\end{array}$ & $\begin{array}{c}\text { Squared } \\
\text { Multiple } \\
\text { Correlation }\end{array}$ & $\begin{array}{c}\text { Cronbach's } \\
\text { Alpha if Item } \\
\text { Deleted }\end{array}$ \\
\hline p1 & 38.17 & 9.730 & 0.582 & .500 & .882 \\
\hline p2 & 37.97 & 8.792 & 0.722 & .868 & .872 \\
\hline p3 & 37.93 & 8.823 & 0.710 & .854 & .873 \\
\hline p4 & 38.00 & 8.690 & 0.762 & .865 & .869 \\
\hline p5 & 38.17 & 9.523 & 0.663 & .716 & .877 \\
\hline p6 & 38.20 & 9.407 & 0.616 & .734 & .880 \\
\hline p7 & 38.33 & 10.437 & 0.525 & .466 & .887 \\
\hline p8 & 38.40 & 9.972 & 0.544 & .811 & .885 \\
\hline p9 & 38.40 & 9.490 & 0.607 & .836 & .881 \\
\hline p10 & 38.33 & 9.954 & 0.570 & .781 & .883 \\
\hline
\end{tabular}

Sumber : Data diolah tahun 2021

Tabel 4. Validitas kualitas Harga (x2)

\begin{tabular}{|l|r|r|r|r|r|}
\hline \multicolumn{7}{|c|}{ Item-Total Statistics } \\
\hline & $\begin{array}{c}\text { Scale Mean if } \\
\text { Item Deleted }\end{array}$ & $\begin{array}{c}\text { Scale } \\
\text { Variance if } \\
\text { Item Deleted }\end{array}$ & $\begin{array}{c}\text { Corrected } \\
\text { Item-Total } \\
\text { Correlation }\end{array}$ & $\begin{array}{c}\text { Squared } \\
\text { Multiple } \\
\text { Correlation }\end{array}$ & $\begin{array}{c}\text { Cronbach's } \\
\text { Alpha if Item } \\
\text { Deleted }\end{array}$ \\
\hline p1 & 38.70 & 10.700 & 0.455 & .429 & .872 \\
\hline p2 & 38.37 & 9.344 & 0.661 & .846 & .857 \\
\hline p3 & 38.40 & 9.007 & 0.756 & .863 & .848 \\
\hline p4 & 38.47 & 8.809 & 0.812 & .898 & .843 \\
\hline p5 & 38.63 & 9.482 & 0.731 & .627 & .851 \\
\hline p6 & 38.67 & 9.747 & 0.661 & .606 & .857 \\
\hline p7 & 38.83 & 10.971 & 0.502 & .611 & .870 \\
\hline p8 & 38.87 & 10.878 & 0.452 & .783 & .872 \\
\hline p9 & 38.90 & 10.645 & 0.475 & .741 & .871 \\
\hline p10 & 38.87 & 10.947 & 0.425 & .582 & .874 \\
\hline
\end{tabular}

Sumber : Data diolah tahun 2021

Tabel 5. Validitas kualitas Keputusan Pembelian (Y)

\begin{tabular}{|l|r|r|r|r|r|}
\hline \multicolumn{7}{|c|}{ Item-Total Statistics } \\
\hline & $\begin{array}{c}\text { Scale Mean if } \\
\text { Item Deleted }\end{array}$ & $\begin{array}{c}\text { Scale Variance } \\
\text { if Item Deleted }\end{array}$ & $\begin{array}{c}\text { Corrected } \\
\text { Item-Total } \\
\text { Correlation }\end{array}$ & $\begin{array}{c}\text { Squared } \\
\text { Multiple } \\
\text { Correlation }\end{array}$ & $\begin{array}{c}\text { Cronbach's } \\
\text { Alpha if Item } \\
\text { Deleted }\end{array}$ \\
\hline p1 & 38.70 & 10.700 & 0.455 & .429 & .872 \\
\hline p2 & 38.37 & 9.344 & 0.661 & .846 & .857 \\
\hline p3 & 38.40 & 9.007 & 0.756 & .863 & .848 \\
\hline p4 & 38.47 & 8.809 & 0.812 & .898 & .843 \\
\hline p5 & 38.63 & 9.482 & 0.731 & .627 & .851 \\
\hline p6 & 38.67 & 9.747 & 0.661 & .606 & .857 \\
\hline p7 & 38.83 & 10.971 & 0.502 & .611 & .870 \\
\hline p8 & 38.87 & 10.878 & 0.452 & .783 & .872 \\
\hline p9 & 38.90 & 10.645 & 0.475 & .741 & .871 \\
\hline p10 & 38.87 & 10.947 & 0.425 & .582 & .874 \\
\hline
\end{tabular}

Sumber : Data diolah tahun 2021

Mengacu kepada Nilai yang tertera pada tabel 3, 4, dan 5 kolom corrected item correlation, maka dapat disarikan bahwa seluruh item tersebut $>0.1663$ dengan alfa $10 \%$ adalah valid.
Sedangkan hasil uji reliabilitas direkapitulasi pada tabel berikut:

Tabel 6. Reliabilitas X1,X2, dan Y

\begin{tabular}{|c|l|c|c|}
\hline No & \multicolumn{1}{|c|}{ Variabel } & Alpha-Cronbach & Keterangan \\
\hline 1 & Kualitas Produk & 0.891 & Reliabel \\
\hline 2 & Harga & 0.871 & Reliabel \\
\hline 3 & Keputusan Pembelian & 0.857 & Reliabel \\
\hline
\end{tabular}

Sumber : Data diolah tahun 2021

\section{Uji Asumsi Klasik}

\section{Uji Normalitas Data}

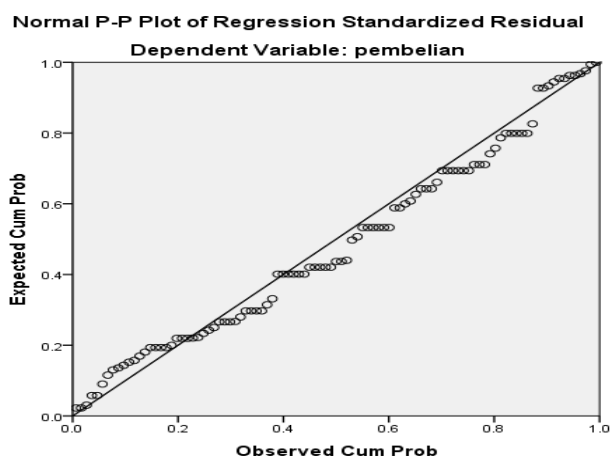

Sumber : Hasil Pengolahan Data SPSS. 24, Tahun 2021

\section{Gambar 2. Hasil Uji Normalitas Data}

Memahami aktualisasi grafik normal plot tersebut di atas, dapat ditetapkan bahwa grafik memperlihatkan bahwa model regresi berperedaran normal dengan kriteria bahwa titik-titik berhambur disekitar garis diagonal.

\section{Uji Multikoliearitas}

\section{Tabel 7. Hasil Uji Multikoliearitas}

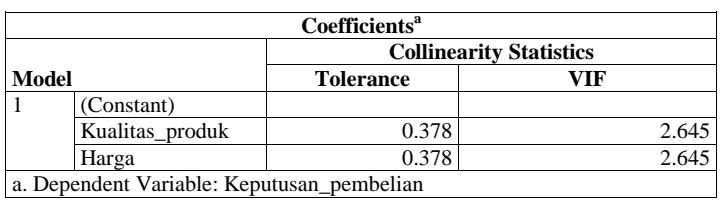

Sumber : Data diolah tahun 2021

Output uji Multikolinieritas 
menampilkan nilai Variance inflation

Factors (VIF) baik kualitas produk maupun harga adalah $2.645<10$, dan angka pada kolom tolerance $0,378>0,10$. Dapat disimpulkan antar variabel independen yaitu kualitas produk dan harga tidak terjadi kasus multikolinieritas.

Uji Heteroskedastisitas

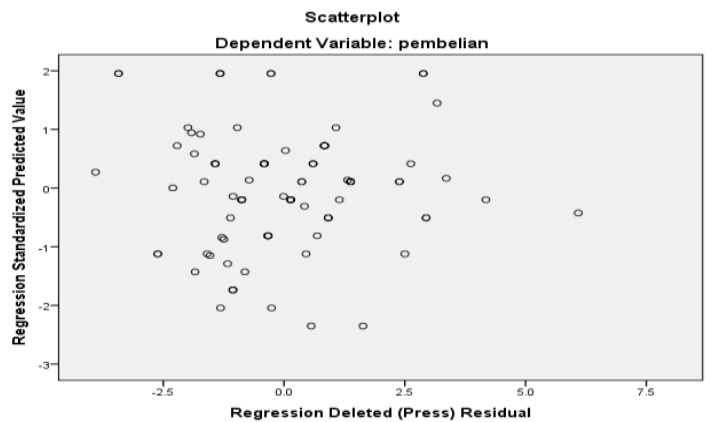

Sumber : Hasil Pengolahan Data Spss.24, Tahun 2021

Gambar 3. Uji heteroskedastisitas

Pada output tersebut menampilkan bahwa titik-titik data menyebar disekitaran angka nol dan tidak bertumpu pada satu titik, serta Penyebarannya tidak membuat suatu pola tertentu. Kesimpulan yang dapat ditarik heteroskedastisitas tidak terjadi pada bentuk regresi ini. Model ini dinyatakan layak dipergunakan untuk melanjutkan penelitian.

\section{Uji Regresi Linear Berganda}

Dari perolehan penyebaran kuesioner/angket dengan sampel 99 responden, ditampakkan hasil SPSS sebagai berikut:
Tabel. 8 coefficients

\begin{tabular}{|c|c|c|c|c|}
\hline \multicolumn{5}{|c|}{ Coefficients $^{\mathrm{a}}$} \\
\hline \multirow{2}{*}{\multicolumn{2}{|c|}{ Model }} & $\begin{array}{l}\text { Unstandardized } \\
\text { Coefficients }\end{array}$ & $\begin{array}{l}\text { Standardized } \\
\text { Coefficients }\end{array}$ & $\mathrm{t}$ \\
\hline & & B & & \\
\hline \multirow[t]{3}{*}{$\mid 1$} & (Constant) & 8.745 & 3.959 & .000 \\
\hline & kualitas_produk & .349 & 4.518 & .000 \\
\hline & Harga & .421 & 5.401 & .000 \\
\hline
\end{tabular}

Sumber : Data diolah tahun 2021

Bentuk regresi berganda diformulasikan dengan rumus sebagai berikut:

$$
\mathrm{Y}=8.745+(-0,349) \mathrm{X}_{1}+0,421 \mathrm{X}_{2}+\mathrm{e},
$$

Angka konstan di tabel menampilkan nilai sebesar 8.745 yang memperlihatkan bahwa faktor kualitas produk dan harga, jika nilainya 0 maknanya keputusan pembelian memiliki tingkat keputusan pembelian sebesar 8,745. kualitas produk mempunyai pengaruh positif yang maknanya jika kualitas produk meningkat $1 \%$ maka keputusan pembelian akan naik sebesar $34,9 \%$, nilai koefisien $\mathrm{X}_{2}$ sebesar 0,421 maknanya variabel harga memiliki pengaruh yang positif yang maknanya jika harga ditingkatkan $1 \%$ maka keputusan pembelian akan naik sebesar $42,1 \%$.

\section{Uji Hipotesis}

Uji t

Berpatokan pada tabel 4 kualitas produk $\left(\mathrm{X}_{1}\right)$ diperoleh nilai $\mathrm{t}_{\text {hitung }}=4.518$ $>1,290$ dan probabilitas 0,00 pada tingkat signifikansi $10 \%$. keadaan ini dapat 
dimaknakan bahwa mempunyai kualitas produk yang semakin bagus, maka keputusan pembelian produk wipol di tengah pandemi wabah COVID-19 Studi Kasus Kecamatan Medan Polonia semakin naik. selanjutnya variabel harga $\left(\mathrm{X}_{2}\right)$ diperoleh nilai $t_{\text {hitung }}=5.401>1,290$ dan probabilitas 0,00 pada tingkat signifikansi $10 \%$. Keadaan ini menunjukkan semakin bagus harga yang dipunyai, maka keputusan pembelian produk wipol saat pandemi wabah covid19 studi kasus Kecamatan Medan Polonia di tengah pandemi wabah COVID-19 Studi Kasus Kecamatan Medan Polonia semakin naik.

\section{Uji F}

Tabel 9 Uji F

\begin{tabular}{|c|c|c|c|c|c|c|}
\hline \multicolumn{7}{|c|}{ ANOVA $^{\mathrm{a}}$} \\
\hline \multicolumn{2}{|l|}{ Model } & $\begin{array}{l}\text { Sum of } \\
\text { Squares }\end{array}$ & Df & Mean Square & & \\
\hline \multirow[t]{3}{*}{1} & Regression & 615.335 & 2 & 307.668 & 116.479 & $.000^{\mathrm{b}}$ \\
\hline & \begin{tabular}{|l|} 
Residual \\
\end{tabular} & 253.574 & 96 & 2.641 & & \\
\hline & Total & 868.909 & 98 & & & \\
\hline \multicolumn{7}{|c|}{ a. Dependent Variable: Keputusan_pembelian } \\
\hline \multicolumn{7}{|c|}{ b. Predictors: (Constant), Harga, kualitas_produk } \\
\hline
\end{tabular}

Sumber : Data diolah tahun 2021

Didasarkan kepada hasil tabel diatas menunjukkan bahwa nilai $F_{\text {hitung }}>F_{\text {tabel }}$ $(136,478>2,70)$ dan nilai signifikan $0,000<0,10 . F_{\text {hitung }}(116,479)>F_{\text {tabel }}(2,14)$ artinya hipotesis $\mathrm{H}_{3}$ pada penelitian ini diterima dengan makna lain kualitas produk dan harga memiliki pengaruh terhadap keputusan pembelian secara bersama berpengaruh signifikan terhadap keputusan pembelian pada produk wipol di tengah pandemi wabah COVID-19 Studi Kasus Kecamatan Medan Polonia.

Uji Koefisien Determinasi (R Square)

Tabel 10. Uji Koefisien Determinasi ( $R$ Square)

\begin{tabular}{|c|c|c|c|c|}
\hline \multicolumn{5}{|c|}{ Model Summary $^{\text {b }}$} \\
\hline Model & $\mathrm{R}$ & R Square & $\begin{array}{c}\text { Adjusted R } \\
\text { Square }\end{array}$ & $\begin{array}{c}\text { Std. Error of the } \\
\text { Estimate }\end{array}$ \\
\hline 1 & $.842^{\mathrm{a}}$ & .708 & .702 & 1.625 \\
\hline
\end{tabular}

Sumber : Data diolah tahun 2021

Dilihat dari nilai yang terterapa pada kolom R Square 0,708 mengindikasikan kualitas produk dan harga sanggup memberikan kejelasan terhadap keputusan pembelian senilai $70,8 \%$ dan kelebihannya 29,2\% dijelaskan oleh unsur lainnya yang tidak mencakup penelitian ini.

\subsection{Pembahasan Penelitian}

Tujuan dari analisis yaitu untuk mengetahui apakah terdapat antara kualitas produk dan harga sebuah pengaruh terhadap keputusan pembelian. analisis ini didapatkan dengan teknik membagikan kuesioner kepada masyarakat Kecamatan Medan Polonia secara acak. Untuk memahami pengaruh kualitas produk $\left(\mathrm{X}_{1}\right)$, harga $\left(\mathrm{X}_{2}\right)$ dan terhadap keputusan pembelian digunakan regresi linear berganda dimana menunjukkan $\mathrm{Y}=8.745+0,349 \mathrm{X}_{1}+$ $0,421 \mathrm{X}_{2}+\mathrm{e}$, artinya kualitas produk dan harga mempunyai pengaruh yang signifikan 
terhadap variabel keputusan pembelian. Atau dengan bahasa lain jika nilai koefisen bernilai positif maka maknanya terjadi antara variabel kualitas produk dan harga hubungan yang positif dengan keputusan pembelian. Hasil Perhitungan Uji F memiliki nilai $F_{\text {hitung }}(116,479)>F_{\text {tabel }}(2,14)$ maka $\mathrm{H}_{3}$ pada penelitian diterima.

Untuk mengetahui uji $\mathrm{t}$ variabel kualitas prdouk $\left(\mathrm{X}_{1}\right)$, dan $\operatorname{harga}\left(\mathrm{X}_{2}\right)$ berpengaruh secara terpisah terhadap variabel keputusan pembelian (Y) dapat di buktikan dengan uji $\mathrm{t}$, diperoleh nilai $\mathrm{t}$ hitung $>\mathrm{t}$ tabel yaitu $4.518>1,290$ dengan probabilitas 0,00 pada tingkat signifikansi 10\%. Keadaan ini membuktikan semakin terjamin kualitas produk yang dimiliki, maka keputusan pembelian produk wipol di tengah pandemi wabah COVID-19 Studi Kasus Kecamatan Medan Polonia semakin tinggi. kemudian pada variabel harga $\left(\mathrm{X}_{2}\right)$ terhadap keputusan pembelian memiliki pengaruh positif dan signifikan dibuktikan dengan perolehan nilai $\mathrm{t}$ hitung $>\mathrm{t}$ tabel yaitu 5.401>1,290 dan probabilitas 0,00 pada tingkat signifikansi $10 \%$. Hal ini mengidentifikasikan semakin bagus harga yang dimiliki, maka keputusan pembelian produk wipol di tengah pandemi wabah covid-19 studi kasus Kecamatan Medan Polonia semakin meningkat pula. Produk wipol harus terus meningkatkan kualitas produk agar konsumen tersebut dapat memberikannya keputusan pembelian kepada produk wipol ditengah era pandemic covid19 ini. Seiring meningkatnya kualitas produk maka para pengguna produk akan tertarik dan berminat untuk menggunakan produk wipol ini dimasa yang akan datang.

Hasil ini sama dengan analisa yang dilakukan oleh Kodu (2013), Igir \& Taroreh (2018), Arianto dan Albani (2018), Putri (2018) dan Kurnia \& Endang (2021) dengan hasil analisa yang menggambarkan kualitas produk dan harga mempunyai pengaruh signifikan terhadap keputusan pembelian. Diketahui pula secara terpisah variabel bebas terhadap keputusan pembelian mempunyai pengaruh yang positif signifikan.

Keadaan ini juga dikuatkan lagi dengan analisa sebelumnya yang dilaksanakan oleh Rosita \& Satyawisudarini (2017) yang mengidentifikasikan bahwa ulasan pembeli terhadap kualitas produk, harga dan keputusan pembelian produk Samesame Clothing secara total ada pada takaran yang baik. didasarkan hasil penelitian tersebut secara terpisah kualitas produk mempunyai pengaruh signifikan terhadap keputusan pembelian dengan kekuatan mempengaruhi total sebesar 
$0,1013$ ( $10,13 \%)$ serta harga memiliki pengaruh signifikan terhadap keputusan pembelian dengan total pengaruh bernilai $0,4865(8,65 \%)$.

Untuk meninjau ukuran sumbangan variabel independen terhadap variabel dependen dengan memakai uji determinan didapatkan nilai $\mathrm{R}$ Square variabel kualitas produk dan harga memiliki angka R Square 0,708 dimaknai oleh semua variabel kualitas produk dan harga berhasil menjelaskan keputusan pembelian sebesar $70,8 \%$ dan kelebihannya 29,2\% dijelaskan oleh unsur lain diluar yang diteliti.

\section{Simpulan dan Saran}

\subsection{Simpulan}

Berpatokan melalui hasil penelitian dan pembahasan maka dapat disimpulkan bahwa:

1. Kualitas peoduk dan harga berpengaruh terhadap keputusan pembelian pada Produk WIPOL Di Tengah Pandemi Wabah COVID-19 Studi Kasus Kecamatan Medan Polonia. Hal ini mengidentifikasikan bahwa semakin kuat kualitas produk dan harga yang ada pada Kecamatan Medan Polonia, maka semakin baik pula keputusan pembelian Produk WIPOL di tengah pandemi wabah COVID-19 .
2. Model penelitian yang dibentuk dinyatakan baik dan dapat diformulasikan sesuai dengan rumus yang telah ditentukan dengan formulasi $\mathrm{Y}=8.475+$ $0,349 X_{1}+0,421 X_{2}+e$,

3. Hasil diperoleh dari uji parsial (uji t) kualitas produk terhadap keputusan pembelian diperoleh nilai $t_{\text {hitung }}=4.518$ $>1,290$ dan probabilitas 0,00 pada tingkat signifikansi $10 \%$, maka secara parsial kualitas produk berpengaruh positif dan signifikan terhadap keputusan pembelianProduk WIPOL di tengah pandemi wabah COVID-19 studi kasus Kecamatan Medan Polonia, dan hasil uji t hargaterhadap keputusan pembelian diperoleh nilai $t_{\text {hitung }}=5.401>1,290$ dan probabilitas 0,00 pada tingkat signifikansi $10 \%$, maka secara terpisah masing masing variabel mempunyai pengaruh positif dan signifikan terhadap keputusan pembelian pada produk wipol di tengah pandemi wabah COVID-19 studi kasus Kecamatan Medan Polonia.

4. Hasil uji $F$ diperoleh $F_{\text {hitung }}>F_{\text {tabel }} F_{\text {hitung }}$ $(116,479)>F_{\text {tabel }}(2,14)$ dengan tingkat probability 0,00 , maka kualitas produk dan harga secara bersama-sama berpengaruh signifikan keputusan pembelianproduk wipol di tengah pandemi wabah COVID-19 studi kasus 
Kecamatan Medan Polonia.

5. Hasil diperoleh dari nilai koefisien determinasi $\left(R^{2}\right)$ sebesarR Square 0,708 artinya kualitas produk dan harga mampu menjelaskan keputusan pembelian sebesar $70,8 \%$ dan sisanya $29,2 \%$ dijelaskan unsur lain diluar penelitian.

\subsection{Saran}

a. Produk wipol memiliki kualitas produk yang cukup baik, terutama dalam kegunaan yang tentunya sangat berguna untuk masa pandemi covid-19 ini dimana produk wipol mampu memberikan kontribusi yang cukup untuk selalu menjadi produk andalan dalam hal kebersihan yang menjadi tolak ukur masa pandemi covid-19 ini, terutama mengenai daya tahan produk karena merupakan salah satu hal yang sangat mempengaruhi keputusan pembelian. Produk wipol harus tetap mempertahankan kualitas produk tanpa menghilangkan ciri khas dari produk agar semua lapisan masyarakat dapat menggunkan produk wipol dan selalu menjaga kebersihan diri dan tetap mematuhi protokol kesehatan tentunya.

b. Harga yang ditawarkan dari produk wipol terbilang cukup ekonomis dan sesuai dengan kebutuhan masingmasing, dimana para pengguna produk wipol juga tetap berharap agar harga dari produk wipol tetap stabil atau tidak mengalami kenaikan dimasa seperti ini dikarenakan kesesuain harga juga sangat mempengaruhi keputusan pembelian.

\section{DAFTAR PUSTAKA}

Arianto, Nurmin. Albani, Adzmi Fahmi. (2018). Pengaruh Kualitas Produk Dan Harga Terjadap Keputusan Pembelian Smartphone Pada Samsung Store Mall Bintaro Exchange. JIMF:jurnal ilmiah majajemen Forkamma. Vol.1 No.3 2018.

Igir, Friani Gloria, Jhony R. E. Tampi Henny Taroreh. (2018). Pengaruh Kualitas Produk Dan Harga Terhadap Keputusan Pembelian Mobil Daihatsu Grand Max Pick Up (Studi pada PT. Astra International Tbk Daihatsu Cabang Malalayang. Jurnal Administrasi Bisnis Volume 6. No 2.

Kodu.(2013). Harga, Kualitas Produk, dan Kualitas Pelayanan Pengaruhnya terhadap Keputusan Pembelian Mobil Toyota Avanza.Jurnal EMBA. Vol.1 No. 3. 2013

Kotler, Armstrong. (2015). "Marketing an Introducing Pretiece Hall twelfth edition", England: Pearson Education, Inc. 
Kurnia, Ayu. Endang.(2021). Pengaruh Kualitas Produk Dan Harga Terhadap Keputusan Pembelian Batik. Jpim:Jurnal Penelitian Ilmu Manjemen.Vol. 6 No. 12021.

Nasution, S. M. (2015). Pengaruh Citra Merek Terhadap Kepuasan pelanggan pada PT.Pegadaian (PERSERO) Kanwil I Medan. Ilmiah Kohesi, 1 (1), 243.

Prastiwi, Devira.(2021). Update Corona Per Senin 8 Februari: 1.166.079 Positif Covid-19, Sembuh 963.028, Meninggal 31.763. https://www. liputan6.com/news/read/4477770/up date-corona-per-senin-8-februari-116 6079-positif-covid-19-sembuh-9630 28-meninggal-31763.

Putri Elisa Desy Rinda.(2018). Pengaruh Kualitas Produk Dan Harga Terhadap Keputusan Pembelian Melalui Minat Beli (Studi Pada Konsumen Wardah Cosmetics Di Indonesia). Skripsi. Universitas Sanata Dharma: Yogyakarta.

Rosita \& Inne Satyawisudarini.(2017). Pengaruh Kualitas Produk Dan Harga Terhadap Keputusan Pembelian Konsumen (Studi Kasus Pembelian). ALMANA:Jurnal manajemen dan bisnis. Vol. 1 No. 32017.

Sangadji, E.M. (2013). Customer Behaviour: Perilaku Konsumen dan Strategi Pemasaran. Jilid 2. Jakarta. Erlangga
Tandjung.(2014). Marketing Management: Pendekatan Pada Nilai-Nilai Pelanggan. Penerbit Bayumedia, Malang 